Article

\title{
Antibiotic and Metal Resistance in Escherichia coli Isolated from Pig Slaughterhouses in the United Kingdom
}

\author{
Hongyan Yang ${ }^{1,2, *}$, Shao-Hung Wei ${ }^{2,3}$, Jon L. Hobman ${ }^{2}$ and Christine E. R. Dodd ${ }^{2}$ \\ 1 College of Life Sciences, Northeast Forestry University, Harbin 150040, China \\ 2 School of Biosciences, University of Nottingham, Sutton Bonington Campus, Sutton Bonington, \\ Leicestershire LE12 5RD, UK; mwei@jhlbiotech.com (S.-H.W.); Jon.Hobman@nottingham.ac.uk (J.L.H.); \\ Christine.dodd@nottingham.ac.uk (C.E.R.D.) \\ 3 JHL Biotech, Zhubei City, Hsinchu County 302, Taiwan \\ * Correspondence: yanghy@nefu.edu.cn
}

Received: 28 September 2020; Accepted: 27 October 2020; Published: 28 October 2020

\begin{abstract}
Antimicrobial resistance is currently an important concern, but there are few data on the co-presence of metal and antibiotic resistance in potentially pathogenic Escherichia coli entering the food chain from pork, which may threaten human health. We have examined the phenotypic and genotypic resistances to 18 antibiotics and 3 metals (mercury, silver, and copper) of E. coli from pig slaughterhouses in the United Kingdom. The results showed resistances to oxytetracycline, streptomycin, sulphonamide, ampicillin, chloramphenicol, trimethoprim-sulfamethoxazole, ceftiofur, amoxicillin-clavulanic acid, aztreonam, and nitrofurantoin. The top three resistances were oxytetracycline $(64 \%)$, streptomycin $(28 \%)$, and sulphonamide $(16 \%)$. Two strains were resistant to six kinds of antibiotics. Three carried the $b l a_{\text {TEM }}$ gene. Fifteen strains $(18.75 \%)$ were resistant to $25 \mu \mathrm{g} / \mathrm{mL}$ mercury and five $(6.25 \%)$ of these to $50 \mu \mathrm{g} / \mathrm{mL}$; merA and $\operatorname{mer} C$ genes were detected in 14 strains. Thirty-five strains ( $43.75 \%$ ) showed resistance to silver, with 19 possessing silA, silB, and silE genes. Fifty-five strains $(68.75 \%)$ were resistant to $8 \mathrm{mM}$ copper or above. Seven contained the $p c o E$ gene. Some strains were multi-resistant to antibiotics, silver, and copper. The results in this study, based on strains isolated between 2007 and 2010, will aid understanding about the effects of strategies to reduce resistance and mechanisms of antimicrobial resistance (AMR).
\end{abstract}

Keywords: antibiotic; metal; resistance; Escherichia coli; slaughterhouse

\section{Introduction}

The discovery and introduction of antibiotics prior to the Second World War marked a pivotal point in the ability of humanity to combat bacterial infections [1]. For over half a century, antibiotics have been widely used in the animal production industry. They have been used not only for disease prevention and treatment, but also for promotion of growth [2]. It is estimated that half of the total antibiotics produced are used for veterinary purposes [3]. The overuse and misuse of antibiotics stimulated the more rapid emergence and spread of antibiotic-resistant bacteria (ARB) and antibiotic resistant genes (ARGs), reducing their therapeutic potential against human and animal pathogens $[4,5]$. The occurrence of multidrug-resistant microorganisms has brought emergent threats to human health.

Metals and metalloids have a long history of human usage in medicine and agriculture. Some toxic metal(loid) compounds, such as mercury and arsenic/antimony compounds, were still used as first-line drugs or preferred-choice chemotherapeutics or antimicrobials in the late twentieth century [6]. Some metals, such as copper and zinc, are still used in animal husbandry as antimicrobials and as essential micro-nutrients and growth stimulants [7-9]. However, the actual concentration of metals 
used in feed samples is far higher than that of the growth requirements $[10,11]$. Overuse and misuse of metals has resulted in their accumulation in the environment, which could promote ARB through co-selection [2,12-14]. Metal pollutants have been hypothesized to be notable contributors to the development of ARB and its determinants [15-17].

Pork is the most consumed meat globally [18]. There are many steps in the production of pork meat from farm to product such as breeding and finishing, animal transportation, slaughter, cutting, processing, and packing, and each step can be a source of bacterial contamination [19-22]. In pig slaughterhouses, many microorganisms such as Salmonella spp., Campylobacter spp., Listeria monocytogenes, and E. coli, which can cause human foodborne disease, have been detected $[23,24]$. E. coli is widely distributed in the environment and can be used to indicate faecal contamination and potential transfer of enteric pathogens [22,25]. Depending on the categories, pathogenic E. coli can cause infection with colonisation of a mucosal site, and is associated with evasion of host defenses, toxin production, and others [26,27]. Many acquired pathogenicity genes, such as ST1 and LT in Enterotoxigenic E. coli, eae in Enteropathogenic E. coli, and ast A in Enteroaggregative E. coli, have been described, with some of these genes carried on plasmids. E. coli strains that carry some of these pathogenicity genes have been found in pork and pigs at slaughter [28-30], and ARB in bacterial isolates from meat is a potential route for transmission into humans. A combination of these virulence factor genes with antibiotic resistance and metal resistance could lead to the development of a serious pathogen. For example, the enterohaemorrhagic E. coli O104:H4 strain, which caused an international disease outbreak in 2011, carried the $v t x 2 a$ gene (Shiga toxin 2), but also had the typical enteroaggregative E. coli pAA virulence plasmid, which codes the AAF adhesion fimbriae (astA gene). This strain was also multidrug resistant and in particular carried a resistance plasmid with genes (TEM-1, CTX-M) for extended-spectrum $\beta$-lactamase [31]. In addition, the emergence of the first plasmid-mediated colistin resistance mechanism, $m c r-1$, in Escherichia coli from pigs, pork products, and humans has been a major concern and heralded the breach of the last line group of antibiotics, polymyxins, which indicated that coordinated global action in the fight against pan-drug-resistant Gram-negative bacteria is urgently needed [32].

A limited number of studies have examined the influence of copper on ARB of the gut microbiota in pigs [33]; from their systematic review of the literature, the authors concluded that the available data 'do not allow excluding the possibility of a positive correlation between copper supplementation above requirements and development of antibiotic resistance'. There are, however, very little data on the co-presence of metal and antibiotic resistance in potentially pathogenic E. coli entering the food chain from pork.

A commonly applied microbial storage technique is to create a dry, low-temperature, and anoxic environment to inhibit the metabolism of microorganisms. After long-term preservation, the survival rate of microbes should be well maintained and microbial activity should get a rapid recovery [34,35]. The liquid nitrogen $\left(-196{ }^{\circ} \mathrm{C}\right)$ lyophilization method and freezing $\left(-20 \sim 80{ }^{\circ} \mathrm{C}\right)$ method are most commonly used [36]. MicroBank ${ }^{\mathrm{TM}}$ beads, as a long-term storage method, have been used for bacteria and fungal storage. The method of storage is simple, economical, and practical [36]. Between 2007 and 2010, over one thousand E. coli strains were isolated in our laboratory from pigs in slaughterhouses in the United Kingdom and stored using MicroBank ${ }^{\mathrm{TM}}$ beads at $-80{ }^{\circ} \mathrm{C}$ [37]. Eighty-one strains were shown to carry the virulence gene ast $A$ associated with enteroaggregative E. coli (EAggEC) strains [37], and thus potentially capable of causing human gastrointestinal disease. We have now further examined these strains to obtain systematic data on their phenotypic and genotypic resistances to antibiotics and metals and to evaluate their co-occurrence. 


\section{Results}

\subsection{Isolate Recovery and EAggEC Genes Re-Confirmation}

All eighty-one putative EAggEC strains were streaked on Brain Heart Infusion (BHI) agar from stock; eighty strains were recovered successfully. All 80 strains gave blue colonies typical of E. coli on Tryptone Bile X-glucuronide (TBX) agar. All strains were oxidase negative. Seventy-seven strains were positive for the indole test, confirming these were E. coli. The EAggEC gene ast $A$ was found in 70 strains and these isolates were studied further.

\subsection{Resistance Prevalence to Antimicrobials}

Strains were tested for resistance to a number of classes of antibiotics commonly used in human medicine that have also been used in animal husbandry, including $\beta$-lactams, and for which resistance can occur in E. coli from animal sources [38]. The phenotypic resistance results are shown in Figure 1. Of 18 antibiotics, resistances to oxytetracycline (OT), streptomycin (S10), sulphonamide (S300), ampicillin (AMP), chloramphenicol (C), trimethoprim-sulfamethoxazole (SXT), ceftiofur (EFT), amoxicillin-clavulanic acid (AMC), aztreonam (ATM), and nitrofurantoin (F) were detected. The top three antibiotic resistances were OT (64\%), S10 (28\%), and S300 (16\%), respectively. There were some strains that showed intermediate resistance, such as to S10 (33\%), AMP (20\%), EFT (5\%), AMC (4\%), and CIP (3\%). Thirteen percent of isolated strains were sensitive to all antibiotics and $9 \%$ of isolated strains showed intermediate sensitivity to all antibiotics; $78 \%$ showed resistance to at least one antibiotic.

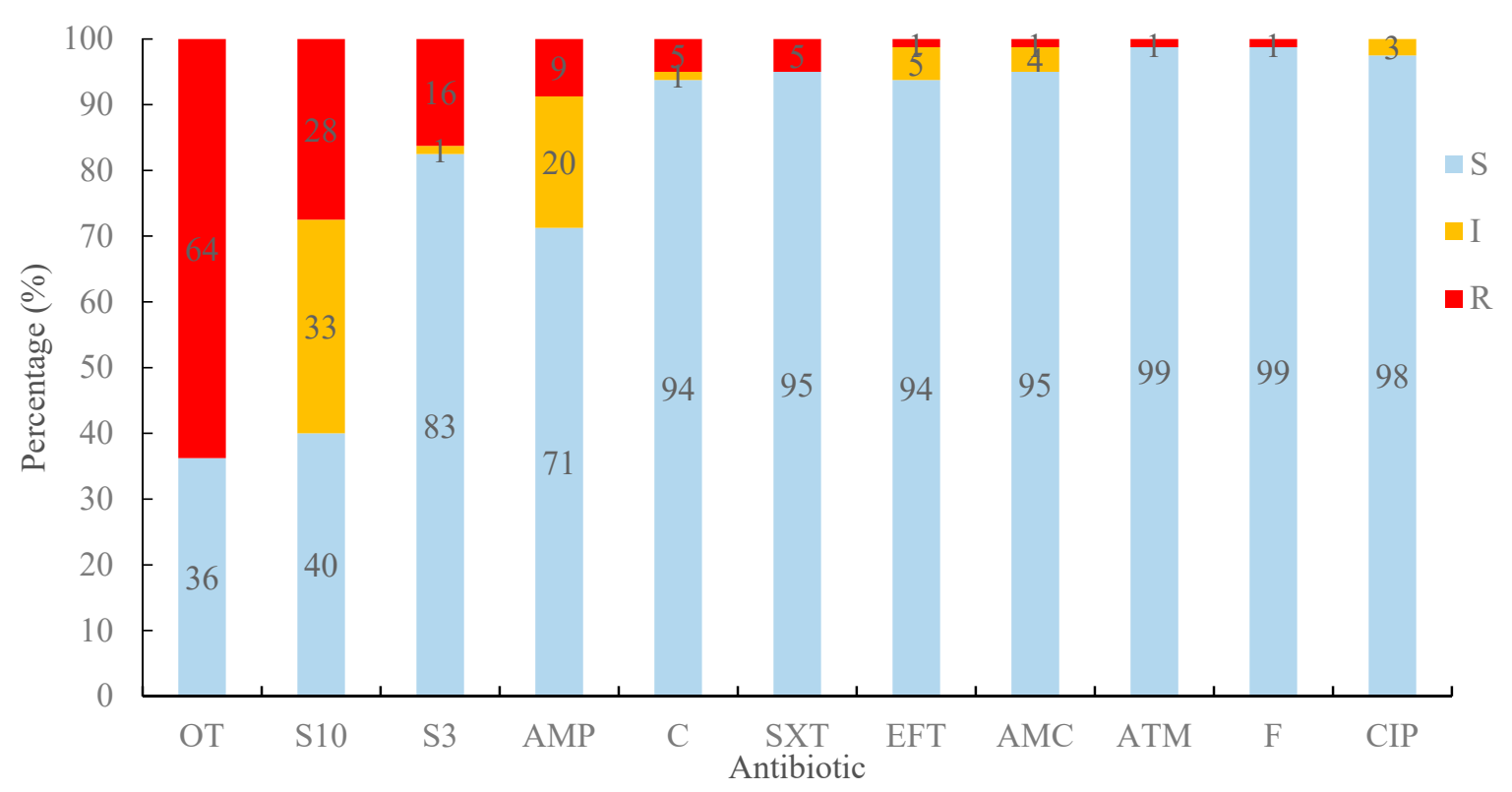

Figure 1. Percentage sensitivity to 18 antibiotics for 80 E. coli strains. Blue bars indicate sensitive (S), yellow bars indicate intermediate sensitivity (I), and red bars indicate lack of sensitivity (R), using Clinical and Laboratory Standards Institute (CLSI) definitions [39-41]. For antibiotic abbreviations, see Table 3.

Some strains were resistant to six antibiotics (Figure 2 and Table 1). All strains were sensitive to ceftazidime (CAZ), cefotaxime (CTX), cefquinome (CFQ), imipenem (IPM), and enrofloxacin (ENR). We also examined resistance to colistin sulfate by agar dilution. The results showed that all strains were sensitive to $8 \mathrm{mg} / \mathrm{L}$ colistin sulfate (Table S1). 


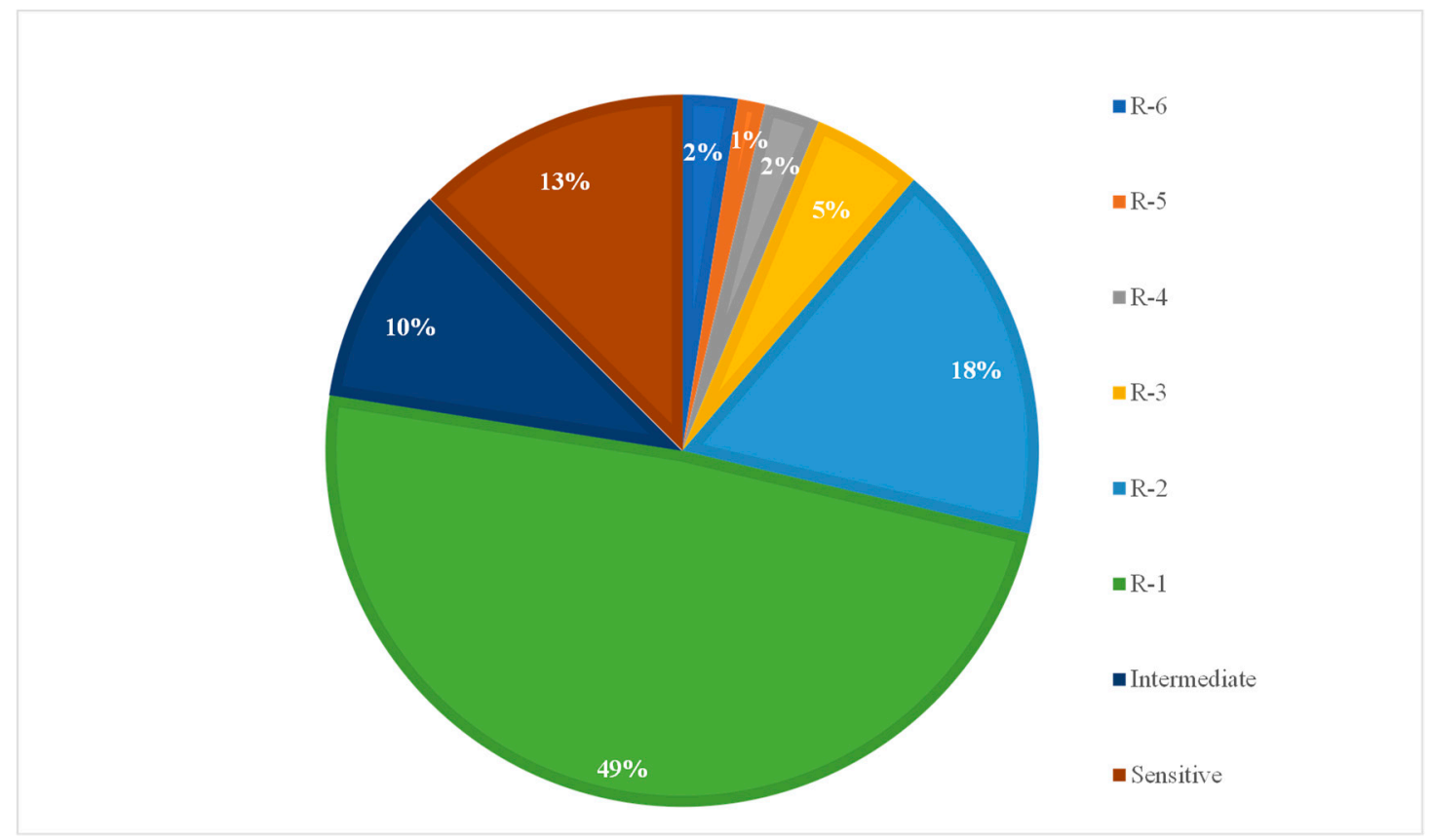

Figure 2. Percentage of E. coli resistant to different numbers of antibiotics. R-1 R-6: resistant to $1 \sim 6$ antibiotics, respectively.

Table 1. Antibiotic resistance combinations found in E.coli isolates.

\begin{tabular}{cccc}
\hline $\begin{array}{c}\text { Number of } \\
\text { Resistance Carried }\end{array}$ & $\begin{array}{c}\text { Total Number } \\
\text { of Isolates }\end{array}$ & $\begin{array}{c}\text { Number of Isolates } \\
\text { Showing Each Phenotype }\end{array}$ & Combination of Resistances \\
\hline 6 & 2 & 2 & AMP *, S10, OT, SXT, S300, C \\
\hline 5 & 1 & 1 & S10, OT, SXT, S300, C \\
\hline 4 & 2 & 1 & OT, SXT, S300, C \\
& & 1 & OT, F, S300, C \\
\hline 3 & 4 & 1 & AMP, S10, EFT \\
& & 1 & AMP, S10, OT \\
& 14 & 1 & S10, OT, S300 \\
\hline 2 & & 1 & AMP, ATM, OT \\
& & 4 & S10, OT \\
& 39 & 1 & OT, S300 \\
\hline 1 & & 30 & S10, S300 \\
\hline Intermediate & 8 & 7 & OT \\
& & 3 & S10 \\
& & 3 & S300 \\
\hline 0 & 10 & 1 & AMP \\
\hline Total & 80 & 10 & S10 \\
\hline
\end{tabular}

* Antibiotic abbreviations: AMP, Ampicillin; S10, Streptomycin; OT, Oxytetracycline; SXT, Trimethoprim-Sulfamethoxazole; S300, Sulfonamide; C, Chloramphenicol; F, Nitrofurantoin; EFT, Ceftiofur; ATM, Aztreonam.

As phenotypic resistance was shown to some $\beta$-lactamases by seven strains, the presence of the antibiotic resistance genes, $b l a_{\mathrm{SHV}}, b l a_{\mathrm{TEM}}, b l a_{\mathrm{OXA}-1}$, and $b l a_{\mathrm{CTX}-\mathrm{M}}$, was examined by specific polymerase chain reaction (PCR). The results specifically showed that three strains, No. 4, No. 7, and No. 61, carried the $b l a_{\text {TEM }}$ gene (Table 2). According to the phenotypic results for antibiotic resistances, these three strains were the top three resistant strains, which were resistant to six, six, and five 
antibiotics, respectively. All three strains were resistant to AMP, but only strain 61 showed resistance to AMC, which can be associated with carriage of a plasmid borne $b l a_{\mathrm{TEM}}$ [42], and none showed typical extended spectrum $\beta$-lactamase (ESBL) resistance. Strains were also examined for the presence of $m c r-1$. No strains were detected carrying the $m c r-1$ gene, confirming the phenotypic result of colistin sulphate sensitivity.

\subsection{Resistance to Mercury}

Various methods for testing for metal resistance exist in the literature. The levels at which toxicity is shown is influenced by many factors, particularly medium composition. Therefore, in this study, known resistant and sensitive strains were included for comparison and the levels at which strains grew or did not grow were compared with these to determine if the test strains were sensitive or resistant.

Phenotypic mercury resistance was tested by growth of strains on media with different concentrations of $\mathrm{HgCl}_{2}$. The level of $\mathrm{HgCl}_{2}$ in Luria-Bertani (LB) agar that completely inhibits the growth of the E. coli sensitive control strain is $25 \mu \mathrm{g} / \mathrm{mL}$. For the tested strains, $15(18.75 \%)$ were resistant to $25 \mu \mathrm{g} / \mathrm{mL}$ mercury and 5 (6.25\%) were resistant to $50 \mu \mathrm{g} / \mathrm{mL}$ mercury (Figure 3a). Especially for strain 38, resistance was shown as same as the positive control (50 $\mu \mathrm{g} / \mathrm{mL}$ ) (E. coli J53 pMG101).
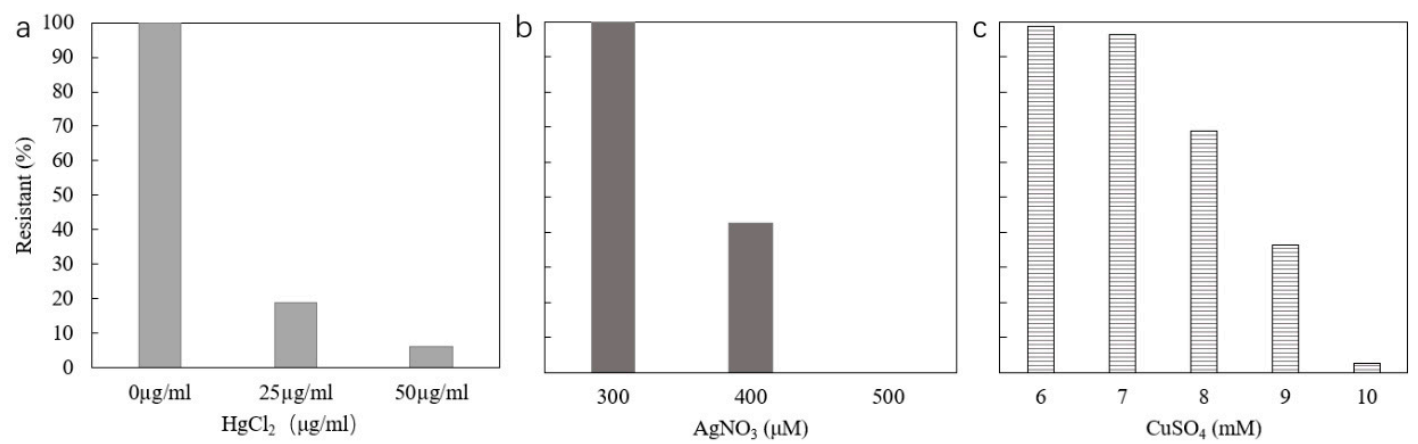

Figure 3. Metal phenotypic resistances of E. coli isolates. (a) E. coli strain J53 was completely inhibited at $25 \mu \mathrm{g} / \mathrm{mL} \mathrm{HgCl}_{2} ;$ (b) silver resistance, E. coli strain 53 was completely inhibited at $400 \mu \mathrm{M} \mathrm{AgNO}_{3}$; (c) copper resistance, E. coli strain ED8739 was completely inhibited at $7 \mathrm{mM} \mathrm{CuSO}_{4}$.

The specific primers of mer $A$, mer $C$, and intl1 genes were used to look for genetic elements associated with mercury resistance and carriage of Tn21-like transposable elements carrying an integron. The mer $A$ and merC genes were detected in 14 of the $80(17.5 \%)$ strains and intl1 was detected in 4 strains (5\%). Two strains, 10 and 14, contained both mer A, merC, and the intl1 genes (Table 2), indictive of carrying a transposon. Combined with phenotypic resistance results, these 14 strains containing mer $A$ and mer $C$ genes all showed resistance to $25 \mu \mathrm{g} / \mathrm{mL}$ mercury. Strain 38, containing mer $A$, mer $C$, and ast $A$, was even resistant to $50 \mu \mathrm{g} / \mathrm{mL}$.

\subsection{Resistance to Silver}

LB agar without salt with different concentrations of $\mathrm{AgNO}_{3}$ was used for detecting phenotypic silver resistance. The results showed all strains could grow at $300 \mu \mathrm{M} \mathrm{AgNO}$. At $400 \mu \mathrm{M} \mathrm{AgNO}$, E. coli sensitive control strain was completely inhibited. Of the tested strains, 35 strains $(43.75 \%)$ showed silver resistance to $400 \mu \mathrm{M} \mathrm{AgNO}_{3}$ (Figure 3b). All strains were sensitive to $500 \mu \mathrm{M} \mathrm{AgNO}_{3}$. Of the 35 phenotypically resistant strains, 19 strains possessed silA, silB, and silE genes (Table 2). 
Table 2. Strains with metal resistance genes and/or $\beta$-lactamase genes and their phenotypic resistances.

\begin{tabular}{|c|c|c|c|c|c|c|c|c|c|c|c|c|c|}
\hline \multirow{2}{*}{\multicolumn{2}{|c|}{ Strain }} & \multicolumn{4}{|c|}{ Silver Resistance } & \multicolumn{3}{|c|}{ Mercury Resistance } & \multirow{3}{*}{$\begin{array}{c}\text { Integron } \\
\text { intl1 }\end{array}$} & \multicolumn{2}{|c|}{ Copper Resistance } & \multicolumn{2}{|l|}{ Antibiotic Resistance } \\
\hline & & \multicolumn{3}{|c|}{ Genotype } & \multirow{2}{*}{$\begin{array}{c}\text { Phenotype } \\
(400 \mu \mathrm{M})\end{array}$} & \multicolumn{2}{|c|}{ Genotype } & \multirow{2}{*}{$\begin{array}{l}\text { Phenotype } \\
(\geq 25 \mu \mathrm{g} / \mathrm{mL})\end{array}$} & & \multirow{2}{*}{$\begin{array}{c}\text { Genotype } \\
p c o E\end{array}$} & \multirow{2}{*}{$\begin{array}{c}\text { Phenotype } \\
\text { ( } \geq 8 \mathrm{mM})\end{array}$} & \multirow{2}{*}{ Phenotype } & \multirow{2}{*}{$\begin{array}{c}\beta \text {-Lactamase } \\
\text { Genes }\end{array}$} \\
\hline ID & Original ID in Reference [37] & silA & silB & sile & & merA & $\operatorname{merC}$ & & & & & & \\
\hline 4 & EAggEC7BP4 & & & & & & & & $+\diamond$ & & $\mathrm{R} \nabla(9 \mathrm{mM})$ & AMP *, S10, OT, SXT, S300, C & $b l a_{\mathrm{TEM}}$ \\
\hline 7 & EAggEC7BP5 & & & & & & & & + & & $\mathrm{R}(9 \mathrm{mM})$ & S10, OT, SXT, S300, C & $b l a_{\mathrm{TEM}}$ \\
\hline 9 & EAggEC9AP1 & + & + & + & $\mathrm{R}$ & + & + & $\mathrm{R}(25 \mu \mathrm{g} / \mathrm{mL})$ & & & $\mathrm{R}(9 \mathrm{mM})$ & OT & \\
\hline 10 & EAggEC8BP5 & & & & $\mathrm{R}$ & + & + & $\mathrm{R}(50 \mu \mathrm{g} / \mathrm{mL})$ & + & & $\mathrm{R}(8 \mathrm{mM})$ & $\operatorname{AMP}(\mathrm{I} \otimes), \operatorname{AMC}(\mathrm{I}), \mathrm{S} 10(\mathrm{I}), \mathrm{OT}, \mathrm{S} 300, \mathrm{SXT}, \mathrm{C}$ & \\
\hline 12 & EAggEC10BP1 & + & + & + & $\mathrm{R}$ & & & & & & $\mathrm{R}(8 \mathrm{mM})$ & S10(I), OT, S300, C, F & \\
\hline 13 & EAggEC9BP1 & + & + & + & $\mathrm{R}$ & & & & & & & AMP, S10, OT & \\
\hline 14 & EAggEC5AP4 & + & + & + & $\mathrm{R}$ & + & + & $\mathrm{R}(25 \mu \mathrm{g} / \mathrm{mL})$ & + & + & & $\mathrm{S} 10(\mathrm{I}), \mathrm{OT}, \mathrm{S} 300, \mathrm{C}(\mathrm{I})$ & \\
\hline 15 & EAggEC9AP5 & + & + & + & $\mathrm{R}$ & + & + & $\mathrm{R}(25 \mu \mathrm{g} / \mathrm{mL})$ & & & $\mathrm{R}(9 \mathrm{mM})$ & OT, CIP(I) & \\
\hline 17 & EAggEC8AP4 & + & + & + & $\mathrm{R}$ & & & & & & $\mathrm{R}(9 \mathrm{mM})$ & $\mathrm{EFT}(\mathrm{I}), \mathrm{S} 10(\mathrm{I})$ & \\
\hline 21 & EAggEC10AP1 & + & + & + & $\mathrm{R}$ & + & + & $\mathrm{R}(25 \mu \mathrm{g} / \mathrm{mL})$ & & & $\mathrm{R}(9 \mathrm{mM})$ & S10(I), OT & \\
\hline 23 & EAggEC 11AP3 & + & + & + & $\mathrm{R}$ & + & + & $\mathrm{R}(25 \mu \mathrm{g} / \mathrm{mL})$ & & & $\mathrm{R}(9 \mathrm{mM})$ & $\mathrm{S} 10(\mathrm{I}), \mathrm{OT}$ & \\
\hline 24 & EAggEC 11AP4 & + & + & + & $\mathrm{R}$ & + & + & $\mathrm{R}(25 \mu \mathrm{g} / \mathrm{mL})$ & & & $\mathrm{R}(9 \mathrm{mM})$ & $\mathrm{S} 10(\mathrm{I}), \mathrm{OT}$ & \\
\hline 25 & EAggEC9AP2 & + & + & + & $\mathrm{R}$ & + & + & $\mathrm{R}(25 \mu \mathrm{g} / \mathrm{mL})$ & & & $\mathrm{R}(9 \mathrm{mM})$ & S10(I), OT & \\
\hline 27 & EAggEC10AP2 & + & + & + & $\mathrm{R}$ & & & & & & & S10, OT & \\
\hline 38 & EAggEC5AO2 & & & & & + & + & $\mathrm{R}(50 \mu \mathrm{g} / \mathrm{mL})$ & & & $\mathrm{R}(9 \mathrm{mM})$ & OT & \\
\hline 41 & EAggEC5AO1 & & & & & + & + & $\mathrm{R}(50 \mu \mathrm{g} / \mathrm{mL})$ & & & $\mathrm{R}(9 \mathrm{mM})$ & OT & \\
\hline 48 & EAggEC5AO3 & & & & & + & + & $\mathrm{R}(50 \mu \mathrm{g} / \mathrm{mL})$ & & & $\mathrm{R}(9 \mathrm{mM})$ & OT & \\
\hline 50 & EAggEC10AO1 & + & + & + & $\mathrm{R}$ & & & & & + & $\mathrm{R}(8 \mathrm{mM})$ & S10(I), S300 & \\
\hline 57 & EAggEC5AS2 & & & & & + & + & $\mathrm{R}(50 \mu \mathrm{g} / \mathrm{mL})$ & & & $\mathrm{R}(9 \mathrm{mM})$ & AMP, ATM, OT & \\
\hline 59 & EAggEC5AS1 & & & & & + & + & $\mathrm{R}(25 \mu \mathrm{g} / \mathrm{mL})$ & & & $\mathrm{R}(9 \mathrm{mM})$ & AMP(I), OT & \\
\hline 61 & EAggEC10AO3 & & & & & & & & & & & AMP, AMC, OT, S300, SXT & $b l a_{\mathrm{TEM}}$ \\
\hline 62 & EAggEC12AO3 & + & + & + & $\mathrm{R}$ & & & & & & & S10(I), OT & \\
\hline 63 & EAggEC12AO4 & + & + & + & $\mathrm{R}$ & & & & & + & & & \\
\hline 70 & EAggEC11AS5 & + & + & + & $\mathrm{R}$ & + & + & $\mathrm{R}(25 \mu \mathrm{g} / \mathrm{mL})$ & & & $\mathrm{R}(9 \mathrm{mM})$ & OT & \\
\hline 74 & EAggEC14AS2 & + & + & + & $\mathrm{R}$ & & & & & + & & & \\
\hline 75 & EAggEC14AS1 & + & + & + & $\mathrm{R}$ & & & & & + & & & \\
\hline 77 & EAggEC15AS1 & + & + & + & $\mathrm{R}$ & & & & & + & $\mathrm{R}(9 \mathrm{mM})$ & S10(I), OT & \\
\hline 78 & EAggEC13AO3 & + & + & + & $\mathrm{R}$ & & & & & + & $\mathrm{R}(10 \mathrm{mM})$ & & \\
\hline
\end{tabular}

$\diamond:$ " + " means that gene was detected; $\nabla:$ " $R$ " means resistant to the concentration indicated in bracket; * For antibiotic abbreviations, see Table 3 . Antibiotic abbreviation means that the strain shows resistance to this antibiotic; $\otimes$ "I" means the resistance is "intermediate sensitivity" to this antibiotic. 
Table 3. Antibiotic assay discs, abbreviations, and amount of antibiotic contained in each disc.

\begin{tabular}{|c|c|c|}
\hline Antibiotic Discs & Content & Antimicrobial Group \\
\hline \multicolumn{3}{|l|}{$\beta$-Lactams } \\
\hline Ampicillin (AMP) & $10 \mu \mathrm{g}$ & Penicillins \\
\hline Amoxicillin-clavulanic acid (AMC) & $20 / 10 \mu \mathrm{g}$ & Penicillin Combination with Beta-lactamase Inhibitor \\
\hline Cefotaxime $(\mathrm{CTX})$ & $30 \mu \mathrm{g}$ & Third Generation Cephalosporin \\
\hline Ceftazidime (CAZ) & $30 \mu \mathrm{g}$ & Third Generation Cephalosporin \\
\hline Ceftiofur (EFT) & $30 \mu \mathrm{g}$ & Third Generation Cephalosporin \\
\hline Cefquinome (CFQ) & $30 \mu \mathrm{g}$ & Fourth Generation Cephalosporin \\
\hline Aztreonam (ATM) & $30 \mu \mathrm{g}$ & Monobactam \\
\hline Imipenem (IPM) & $10 \mu \mathrm{g}$ & Carbapenem \\
\hline \multicolumn{3}{|l|}{ Aminoglycoside } \\
\hline \multicolumn{3}{|l|}{ Quinolones } \\
\hline Ciprofloxacin (CIP) & $5 \mu \mathrm{g}$ & Fluoro-quinolones \\
\hline Enrofloxacin (ENR) & $5 \mu \mathrm{g}$ & Fluoro-quinolones \\
\hline Nalidixic acid (NA) & $30 \mu \mathrm{g}$ & Quinolones \\
\hline \multicolumn{3}{|l|}{ Sulphonamide/complex } \\
\hline Trimethoprim-sulfamethoxazole (SXT) & $1.25 / 23.75 \mu \mathrm{g}$ & Folate Pathway Inhibitors \\
\hline Sulfonamide (S300) & $300 \mu \mathrm{g}$ & Folate Pathway Inhibitors \\
\hline $\begin{array}{c}\text { Phenicol } \\
\text { Chloramphenicol (C) }\end{array}$ & $30 \mu \mathrm{g}$ & Phenicols \\
\hline Tetracycline & & \\
\hline Oxytetracycline (OT) & $30 \mu \mathrm{g}$ & Tetracyclines \\
\hline Nitrofuran derivative & & \\
\hline Nitrofurantoin (F) & $300 \mu \mathrm{g}$ & Nitrofurans \\
\hline
\end{tabular}

\subsection{Resistance to Copper}

In this study, E. coli ED8739 and E. coli ED8739 pRJ1004 were used as negative and positive controls, respectively. The results showed that $E$. coli ED8739 could grow at $6 \mathrm{mM} \mathrm{CuSO}_{4}$ or below, but could not grow at $7 \mathrm{mM}$ copper. However, E. coli ED8739 pRJ1004 expressed extremely strong resistance to copper, being resistant to $20 \mathrm{mM} \mathrm{CuSO}_{4}$. Compared with E. coli ED8739, most strains showed resistance to only $7 \mathrm{mM}$ copper (Figure 3c). Fifty five strains $(68.75 \%)$ were resistant to $8 \mathrm{mM}$ copper, twenty nine $(36.25 \%)$ strains were resistant to $9 \mathrm{mM}$ copper, and two strains were resistant to $10 \mathrm{mM}$ copper. Over $10 \mathrm{mM}$, no strains showed resistance.

At the same time, we examined all strains for carriage of $p c o E$. The $p c o E$ gene was detected in seven strains (Table 2). Two strains (No. 50 and No. 77) with the $p c o E$ genes showed phenotypic resistance to $8 \mathrm{mM}$ and $9 \mathrm{mM}$ copper, while one strain (No. 78) showed resistance to $10 \mathrm{mM}$ (Table 2). The other four strains (No. 14, No. 63, No. 74, and No. 75) containing the pcoE gene did not show resistance to $8 \mathrm{mM}$ copper, only to $7 \mathrm{mM} \mathrm{CuSO}_{4}$, slightly above the basal copper tolerance of laboratory E. coli strains (Table 2 and Table S1). Most other strains phenotypically copper resistant at $8 \mathrm{mM}$ did not contain a $p c o E$ gene (Table S1).

\section{Discussion}

Antimicrobial resistance (AMR) has been characterized as a global public health crisis that must be managed with the utmost urgency [43]. The evolution of AMR is a complex, multifactorial issue [44]. The lack of understanding for the potential dangers of inappropriate use, as well as the widespread access to antimicrobials, have led to the current AMR crisis [45]. Several strategies, such as antimicrobial stewardship programs, preventing the misuse of antibiotics, and promoting the discovery of new antimicrobial agents, have been developed in recent years to slow this progression [44]. Antimicrobial resistance surveillance at different periods will aid people to know about the effects of these strategies and pathologic mechanisms of AMR. To the best of our knowledge, this is the first study to examine 
the prevalence of the co-occurrence of both antibiotic resistance and metal resistance in E. coli from slaughterhouses in the United Kingdom.

In this study, we focused on AMR of E. coli strains isolated from pig slaughterhouses in 2007, 2009 , and 2010. We used the strain stocks stored on Microbank ${ }^{\mathrm{TM}}$ beads at $-80{ }^{\circ} \mathrm{C}$. This method is often used for long-term storage of microorganisms [36,46,47]. In this study, of the 81 strains, which were stored in Microbank ${ }^{\mathrm{TM}}$ in 2009 and 2010, 80 live strains were recovered, giving a recovery rate of $98.8 \%$, which indicated that Microbank ${ }^{\mathrm{TM}}$ could be used to store $E$. coli for at least seven years. However, during storage, some characteristics appeared to have changed. For example, when originally isolated, all strains were detected with the plasmid borne ast $A$ gene, which is found among certain categories of diarrhoeagenic E. coli [48]. After storage, only 70 strains were detected carrying the $a s t A$ gene, suggesting plasmid loss on recovery. Three strains were indole negative, although originally characterised as indole positive. These results showed that long-term storage may lead to the instability of some E. coli strain characteristics.

From phenotypic results, $78 \%$ of analysed strains were resistant to between one and six antibiotics. Multi-drug resistance prevalence was $28.8 \%$, which was similar to reports from other places at the same time. For instance, Sheikh et al. from Canada (with pork, beef, poultry, and turkey samples) and Llorente et al. from Buenos Aires (with beef samples) reported a multi-drug resistance prevalence of $28.1 \%$ and $27.8 \%$, respectively [49,50]. From the Tadesse et al. review from 1950 to 2002 (of human and food samples from beef, pork, poultry), a prevalence of multi-drug resistance of $59.1 \%$ in beef and $53.7 \%$ in pork was found [51]. The results in the current study showed that the multi-drug resistance prevalence in pigs in the United Kingdom between 2007 and 2010 was very low. In contrast, recent investigations in Tamaulipas, Mexico showed that the prevalence of antimicrobial resistance amounted to $92 \%$ in retail samples of beef and pork [30].

Tetracyclines, as a group of antibiotics, are a cause for special attention because large quantities are applied in the therapy in human and animal infections as well as in some countries in animal feed as growth promoters. However, only a small amount of tetracyclines can be metabolized or absorbed by humans and animals. Residues of these antibiotics are accumulated in the environment and may lead to the occurrence of resistant species [52]. Oxytetracycline (OT), belonging to the tetracycline group of antibiotics, is a broad-spectrum antibiotic, active against a wide variety of bacteria [53]. In this study, of all resistances, OT resistance was predominant $(n=51 ; 64 \%)$, with some strains showing only tetracycline resistance, but others showing multi-drug resistance (Figure 1 and Table 1 ). Similar results were reported in ready-to-eat meat (66.7\%) [54], pork (43.8\%) [55], beef $(74 \%)$ [56], and chicken (97\%) [57]. The AMR prevalence in Enterobacteriaceae isolates from slaughtered pigs has been shown to be 31.8\% in Salmonella in 2004-2005 in Ethiopia [58] and 56\% in 2013-2014 in Italy [59]; $22 \%$ of E. coli in 2007 in Denmark [60]; and 78.2\% in Yersinia enterocolitica in 2013-2014 in Italy [61]. In this current study, $64 \%$ of all E. coli strains showing resistance was higher than that in Denmark in 2007. In another report, for Enterococcus faecium and E. faecalis isolated from pigs, the resistance level of $82 \%$ in the United Kingdom was higher than the average level (67.4\%) in the European Union (EU) in 2013-2014 [62]; the reason for this was unclear. A recent report on resistance in wild pigs showed that, of 115 E. coli strains, none were resistant to OT. The abundant prevalence of tetracycline resistance represents a useful marker to monitor antimicrobial-resistant bacteria $[63,64]$. These results of OT resistance may represent a genetic archaeology of the use of veterinary antimicrobials [38]. Streptomycin (S10) $(n=26 ; 33 \%)$ and sulfonamide (S300) $(n=13 ; 16 \%)$ were the other two antibiotics to which a higher percentage of all strains were resistant in this study. This result was similar to previous reports $[55,65,66]$.

The $\beta$-lactams are the most widely used class of antimicrobials worldwide, representing over $65 \%$ of the global market [67]. From the late 1990s, multidrug-resistant Enterobacteriaceae (mostly E. coli) that produce extended spectrum $\beta$-lactamases (ESBLs) have emerged within the community setting as an important cause of urinary-tract infections [68]. Extended spectrum $\beta$-lactamases (ESBLs), one group of $\beta$-lactamase, have the ability to hydrolyse and cause resistance to various types of the 
newer $\beta$-lactam antibiotics, including the extended-spectrum (or third-generation) cephalosporins (e.g., cefotaxime, ceftriaxone, ceftazidime) and monobactams (e.g., aztreonam), but not the cephamycins (e.g., cefoxitin and cefotetan) and carbapenems (e.g., imipenem, meropenem, and ertapenem) [69]. In this study, we have also detected phenotypic resistances to $\beta$-lactams such as ampicillin (AMP, 9\%), amoxicillin-clavulanic acid (AMC, 1\%), ceftiofur (EFT, 1\%), and aztreonam (ATM, 1\%).

For the genotypic detection of $\beta$-lactam resistance, PCR amplification of the $b l a_{\mathrm{TEM}}, b l a_{\mathrm{SHV}}$, and bla $\mathrm{CTX-M}$ genes is often used because it is straightforward and cost-effective [68] and, in one report, the $b l a_{\text {TEM }}$ gene was detected as the most prevalent resistance gene in isolates from poultry, beef, and pork in Czech Republic [55]. In this study, the presence of bla $a_{\mathrm{TEM}}, b l a_{\mathrm{SHV}}$, and bla $a_{\mathrm{CTX}-\mathrm{M}}$ genes was determined. The result showed that the TEM gene existed in three strains (Table 2). Between 2007 and 2010, a large number of ESBL-containing resistant strains were identified in the EU $[70,71]$. Different results in our study might be because of differences in the antibiotics used in animal husbandry, which may influence resistance carriage. While some characteristics of strains changed during storage, particularly the loss of the ast $A$ gene, which is usually plasmid carried, it could be suggested that resistance plasmids had also been lost. However, the loss of ast $A$ was seen in only $12.5 \%$ of strains, thus plasmid loss is unlikely to account for the low level of ESBL resistance seen here. The $b l a$ TEM gene encodes the production of $\beta$-lactamase enzymes that hydrolyze the $\beta$-lactam ring and inactivate those $\beta$-lactams [72]. Beta-lactamases are the principal mechanism of bacterial resistance to beta-lactam antibiotics. AmpC beta-lactamases and/or extended-spectrum beta-lactamases (ESBLs) are of particular concern for the prevalence of multidrug-resistant Gram-negative bacteria [73]. In E. coli, ESBLs were plasmid-encoded [74], while AmpC beta-lactamase production was chromosomally mediated [73]. Combined with the result in this study, we deduced that the $\beta$-lactam resistance seen in the other strains may be conferred by upregulation of the chromosomal ampC gene found in all E. coli [73], which concurs with the results seen in other studies [38].

According to the phenotypic results, two of the three strains (No. 4 and No. 7) containing the TEM gene showed multi-drug resistance to six antibiotics (AMP, S10, OT, S300, SXT, and C). The other one (No. 61) was resistant to five antibiotics (AMP, AMC, OT, S300, and SXT) (Table 2). However, none of these strains showed typical phenotypic ESBL resistance patterns associated with carriage of the TEM gene. The presence of the bla $a_{\text {TEM }}$ gene might be associated with the co-occurrence of genes for resistance to AMP, OT, S300, and SXT. At the same time, strains No. 4 and No. 7 contained the intl1 gene (Table 2). According to the report of Fernandez-Alarcon, et al. [75], IncA/C plasmids carrying $b l a_{\mathrm{TEM}}$ and intl1 and genes conferring resistance to gentamicin, kanamycin, streptomycin, trimethoprim/sulfamethoxazole, sulfoxazole, chloramphenicol, and tetracycline have been described. In this study, whether strains No. 4 and No.7 contain IncA/C plasmids needs to be further researched.

Apart from antibiotics, a similar issue of resistance also exists for metals. Metals also exhibit antimicrobial features. Even when no antimicrobial compounds are used, certain metals can maintain or even increase bacterial resistance against certain agents [76]. In medicine and agriculture, the most commonly used metals have probably been mercury $(\mathrm{Hg})$, copper $(\mathrm{Cu})$, silver $(\mathrm{Ag})$, arsenic (As), and antimony (Sb) [6]; zinc and copper are frequently used as feed supplements for pigs. In this study, we examined $\mathrm{E}$. coli resistance to $\mathrm{Hg}, \mathrm{Cu}$, and $\mathrm{Ag}$. For $\mathrm{Hg}, 15$ strains (18.75\%) were phenotypically resistant to $25 \mu \mathrm{g} / \mathrm{mL} \mathrm{HgCl}_{2}$. Of these, 14 strains $(93.3 \%)$ contained both mer $A$ and merC genes (Table 2). The mercuric ion reductase (MerA), an enzyme that catalyzes the conversion of the thiol-avid $\mathrm{Hg}$ (II) to volatile, uncharged $\mathrm{Hg}(0)$ that lacks significant affinity for any liganding functional groups, is the heart of the mercury resistance (HgR) mechanism [77]. MerC is an operon-encoded transmembrane protein, particularly found in Tn21-family transposons, which pumps ionic mercury into the cytosol [78]. MerC may be needed under conditions of very high $\mathrm{Hg}$ (II) exposure [79] and is characteristic of Tn21-family transposons. Intl is a gene encoding an integrase, which is a necessary component of an integron, and many class 1 integrons (intl1) carrying antibiotic resistance cassettes are found on Tn21-like transposons [80]. In this study, there were two strains 
possessing $m e r A, m e r C$, and intl1 genes (Table 2). The results indicated that a Tn21-like transposon is likely to be present in these two strains.

In this study, to test bacterial silver resistance, silver concentrations of $0 \sim 600 \mu \mathrm{M}$ were set up according to previous research [81]. The results showed that the sensitive strain E. coli J53 can grow up to $300 \mu \mathrm{M}$ of $\mathrm{AgNO}_{3}$, while the resistant strain E. coli J53 with plasmid pMG101 (J53 pMG101) continues to grow up to $600 \mu \mathrm{M}$. Gupta et al. reported that E. coli J53 could grow up to $100 \mu \mathrm{M}$ of $\mathrm{AgNO}_{3}$ [81]. Although these differences in resistance levels shown between two studies are possibly due to experimental conditions and operators, resistance at $400 \mu \mathrm{M}$ of $\mathrm{AgNO}_{3}$ was significantly correlated to the presence of genotypic resistances genes $(r=0.6)$, and thus could be taken as the silver concentration that denotes phenotypic resistance. The genes for Ag+ resistance are a cluster of seven genes (and two open reading frames of unknown function), which is organized into three divergently transcribed units [82]. SilE is a periplasmic metal-binding protein that has been purified and measured for $\mathrm{Ag}^{+}$-binding properties and is highly expressed when silver ions are present. SilS and SilR are a presumed two-component membrane sensor and transcriptional responder, and SilCBA and SilP are a presumed $\mathrm{Ag}^{+}$efflux chemiosmotic cation-proton antiporter and a P-type ATPase, respectively. In this study, three $\mathrm{Ag}^{+}$resistance genes silA, silB, and silE were examined. The results showed that $23.75 \%$ of strains possessed these three genes and expressed phenotypic silver resistance, which may suggest that silver compounds have been widely used as antimicrobials [83]. Of these $23.75 \%$ of strains, there were eight strains that also possessed mercury-resistance genes (Table 2). That means these strains possess multi-metal resistances. In addition, there were another $20 \%$ of strains that showed phenotypic resistance without silA, silB, and silE genes.

Copper is an essential metal to aerobic forms of life, being involved in donating or accepting electrons in redox-active enzymes, or in the electron transport chain [6,84]. It is commonly used in the farming of pigs, but the actual concentration of copper in the feed is 3-9 times higher than that of the growth requirements [10]. In Europe, copper sulphate in pig feed is permitted at $125-250 \mathrm{mg} / \mathrm{kg}$ feed (equivalent to $0.78-1.56 \mathrm{mM}$ ) and has been shown to stimulate the growth rate of piglets and, at these levels, is known to modify the gastrointestinal microbiota composition [85]. In this study, three strains were resistant to more than $8 \mathrm{mM}$ copper and one of them (No. 78) was resistant to $10 \mathrm{mM}$ copper (Table 2). However, the phenotypic results of most strains for copper resistance did not match the genotypic ones as seven strains $(8.75 \%)$ possessed the pcoE gene, which is an indicator for carriage of the pco copper resistance system, but did not show copper resistance at the level that the positive control (E. coli ED8739 pRJ1004) demonstrated (Figure 3c). This result may be due to copper resistance being conferred after a succession of events from a combination of both chromosomal and plasmid-encoded genes [86], or that an incomplete pco system is present. The $p c o$ and sil operons have regularly been found together in an identical arrangement in plasmids, but also on the chromosome [6]. In this study, we further found that all strains possessing the $p c o E$ gene also contained the sil genes.

Noticeably, one strain (No. 14) containing mer, intl1, sil, pcoE, and ast $A$ genes was detected (Table 2). This strain was phenotypically resistant to mercury $(25 \mu \mathrm{g} / \mathrm{mL})$, silver $(400 \mu \mathrm{M})$, and antibiotics (oxytetracycline and sulfonamide). That means there were co-resistant strains in the food chain. The result also indicated there are high-risk, multi-drug (metal and antibiotics) resistant strains in the food chain that carry genes for potential pathogenicity. Fortunately, no phenotypic copper resistance was detected in this strain.

It is of particular concern that exposure to heavy metals could favor co-selection of antimicrobial resistances [87]. The determination of correlations occurring between antibiotic and heavy metal resistances is considered an important tool to gain new insight into the not yet fully characterized mechanism(s) leading to co-selection [88]. In this study, correlation of metal resistance and antibiotic resistance presence was examined (Table 2). Oxytetracyline was common in all metal resistant strains; 13 of 19 strains with silver resistance showed OT resistance and 14 of 14 strains with mercury resistance showed OT resistance. However, OT resistance was also common in non-metal resistant strains and, for the 80 strains, the Pearson correlation coefficient of OT with silver was $r=0.054$, showing no 
specific correlation; for OT with mercury, it was $r=0.34$, showing weak correlation. However, for all silver resistant strains, OT resistance with silver was $r=0.79$ and that of OT with mercury was $r=1$. The results showed that a correlation existed for OT and silver and a strong correlation existed for OT and mercury. These results also indicate co-selection between antibiotic and metal might exist in E. coli isolates in this study.

The strains used in this study were collected between 2007 and 2010. There have since been very significant reductions in antibiotic usage in pig husbandry in the United Kingdom, including in use of human critical antibiotics such as fluoroquinolones, 3/4 generation cephalosporins, and colistin [89], and there are plans to remove zinc as a supplement in pig feed in the EU. These data, therefore, provide an historic baseline against which the results of these changes in antimicrobial usage can be measured. The retention of resistances to antimicrobials no longer in active use may demonstrate a genetic archaeology of the use of veterinary antimicrobials and provide a better understanding of the drivers for their presence.

\section{Materials and Methods}

\subsection{Isolate Recovery and Re-confirmation}

Brain Heart Infusion agar (Sigma, UK) was used to recover the isolates stored in Microbank (Pro-Lab, UK) beads at $-80{ }^{\circ} \mathrm{C}$. The inoculated plates were incubated at $37{ }^{\circ} \mathrm{C}$ for $24 \mathrm{~h}$. LB agar (Sigma, UK) was used to cultivate the isolates. Growth on TBX agar (Sigma, UK) was used to re-confirm the isolates as E. coli. An oxidase test was performed using a strip (MB0266A, Oxoid, UK) as directed by the manufacturer. An indole test was performed using the RapID Spot Indole Reagent (R8309002, SLS, UK). Several drops of Indole Spot Reagent were placed on a piece of filter paper. With an inoculating loop a portion of an 18-24 hour growth isolated colony was picked up and rubbed onto the reagent saturated area. A positive reaction was denoted by the appearance of a blue to blue-green colour change on the bacterial smear within 10 seconds. Negative reactions remained colourless or light pink.

\subsection{Antibiotic Sensitivity Tests}

The disc diffusion antibiotic sensitivity tests were carried out according to Clinical and Laboratory Standards Institute (CLSI) guidelines [40,41]. Four or five bacterial colonies were taken from LB plates, which had been incubated overnight at $37^{\circ} \mathrm{C}$. The colonies were suspended in $5 \mathrm{~mL}$ of Mueller-Hinton broth (Oxoid, UK) to a $0.5 \mathrm{McF}$ arland standard concentration. Then, $100 \mu \mathrm{L}$ of the culture was pipetted onto the surface of a $25 \mathrm{~mL}$ Mueller-Hinton agar plate (Oxoid, UK), and the inoculum was distributed by spreading using a sterile swab. The plates were left to dry at room temperature (for no more than $15 \mathrm{~min}$ ), and the antibiotic discs were applied using a disc dispenser (Pro-lab, UK). The plates were then incubated at $37^{\circ} \mathrm{C}$ for $18-24 \mathrm{~h}$, and the results were recorded by measuring the inhibition zone diameter across the disc and interpreted according to standard measurement tables $[40,41]$. The seventeen antibiotics used in the tests are listed in Table 3; discs were supplied by Oxoid (UK), except for Cefquinome (Bioconnection, UK), and the quality control strains used were E. coli ATCC 25922 (ESBL negative) and E. coli NCTC 13353 (ESBL positive CTX-M-15). For phenotypically colistin-resistant isolates, the agar dilution method was used according to the CLSI procedure [39]. Isolates showing growth above the concentration of $8 \mathrm{mg} / \mathrm{L}$ colistin were regarded as resistant [90].

\subsection{Metal Sensitivity Tests}

$\mathrm{Ag}+$ resistance was assayed on $\mathrm{LB}$ agar plates without added $\mathrm{NaCl}$ [72] with the addition of $\mathrm{AgNO}_{3}$ (Sigma Aldrich, 209139) at concentrations of $0 \mu \mathrm{M}, 100 \mu \mathrm{M}, 200 \mu \mathrm{M}, 300 \mu \mathrm{M}, 400 \mu \mathrm{M}, 500 \mu \mathrm{M}$, and $600 \mu \mathrm{M}$. Exponential-phase cultures were streaked on plates and incubated at $37^{\circ} \mathrm{C}$ for $16 \mathrm{~h}$ before recording growth [91]. E. coli strain J53 and E. coli strain J53 pMG101 were used as negative and positive control, respectively [81]. Phenotypic mercury resistance was tested by growth on LB 
agar supplemented with $\mathrm{HgCl}_{2}$. Concentrations of $0,25 \mu \mathrm{g} / \mathrm{mL}$, and $50 \mu \mathrm{g} / \mathrm{mL}$ were prepared by the addition of $50 \mathrm{mg} / \mathrm{mL} \mathrm{HgCl}_{2}$ to sterilised LB agar. Strains were streaked on the plates and incubated at $37^{\circ} \mathrm{C}$ for $16 \mathrm{~h}$ before recording growth. For copper sensitivity tests, LB agar plates were supplemented with $\mathrm{CuSO}_{4}$ (Sigma Aldrich, C1297, UK) (0, 2, 4, 5, 6, 7, 8, 9, 10, 11, 12, 14, 16, 18, and $20 \mathrm{mM}$ ). The pH of the agar was adjusted to pH 7.2 [92]. E. coli ED8739 [93] and E. coli ED8739 pRJ1004 (plasmid with pco genes) [94] were used as negative and positive controls, respectively.

\subsection{PCR Detection of Genetic Elements Carrying Metal and Antibiotic Resistance Genes}

Bacterial DNA was extracted by dispersing two colonies of $E$. coli from an overnight culture on LB agar into $100 \mu \mathrm{L}$ of sterile $1 \times$ TE buffer (10 mM Tris-Cl, 1 mM EDTA buffer, $\mathrm{pH}$ 7.6). The suspension was heated to $100{ }^{\circ} \mathrm{C}$ for $30 \mathrm{~min}$ to rupture bacterial cells (Eppendorf Thermomixer Comfort, Germany) and then centrifuged (Sigma, UK) at 13,000 $\times g$ for $15 \mathrm{~min}$. The crude DNA in the supernatants was transferred into sterile microcentrifuge tubes and stored at $-20^{\circ} \mathrm{C}$ until use (total DNA). All primers in this study were synthesized by Sigma-Aldrich Life Science, UK. The primer sequences and expected PCR product sizes are given in Table 4. Unless indicated otherwise, E. coli ATCC 25922 was used as a negative control. A 100 bp DNA size marker (NEB, UK) was used in each gel, except where indicated otherwise.

For enteroaggregative (EAggEC) virulence plasmid gene ast $A$ detection, total DNA $(1 \mu \mathrm{L})$ was used in a $25 \mu \mathrm{L}$ reaction mixture that contained $2.5 \mu \mathrm{L} 10 \times$ reaction buffer (ThermoFisher Scientific, UK), $2 \mu \mathrm{L}(2.5 \mathrm{mM})$ of each of the dNTPs, $1 \mu \mathrm{L}(10 \mu \mathrm{M})$ of each primer, $0.125 \mu \mathrm{L}(5 \mathrm{U} / \mu \mathrm{L})$ DreamTaq (ThermoFisher Scientific, UK), and $17.375 \mu \mathrm{L}$ of molecular biological grade water. E. coli H10407 [95] was used as positive control. A programmable C1000TM Thermal cycler (Bio-Rad, UK) was used to carry out the reactions under the following conditions: one cycle of denaturation for $5 \mathrm{~min}$ at $94{ }^{\circ} \mathrm{C}$ and then 30 cycles comprising $1 \mathrm{~min}$ at $94^{\circ} \mathrm{C}, 1 \mathrm{~min}$ at $55^{\circ} \mathrm{C}$, and $1 \mathrm{~min}$ at $72^{\circ} \mathrm{C}$, with a final extension of $10 \mathrm{~min}$ at $72{ }^{\circ} \mathrm{C}$ [37].

For the detection of $\beta$-lactamase genes, PCR was used to examine for $b l a_{\mathrm{SHV}}, b l a_{\mathrm{TEM}}, b l a_{\mathrm{OXA}-1}$, and $b l a_{\text {CTX-M }}$ genes [96]. Presence of the $m c r-1$ resistance gene was used to determine resistance to colistin sulfate. The reaction mixture was as described above. E. coli NCTC 13353 was used as a positive control for CTX, E. coli NCTC 13352 as a positive control for TEM, E. coli strain A2.5 [38] as a positive control for OXA, and Klebsiella pneumoniae NCTC 13368 as a positive control for SHV. E. coli NCTC 13846 was used as a positive control for mcr-1. Except for $m c r-1$, PCR amplification was one cycle of denaturation for $5 \mathrm{~min}$ at $94^{\circ} \mathrm{C}$ followed by 30 cycles of $30 \mathrm{~s}$ at $94{ }^{\circ} \mathrm{C}, 30 \mathrm{~s}$ at $55^{\circ} \mathrm{C}$, and $1 \mathrm{~min}$ at $72{ }^{\circ} \mathrm{C}$, with a final extension of $7 \mathrm{~min}$ at $72{ }^{\circ} \mathrm{C}$ [38]. The program for $m c r-1$ was $10 \mathrm{~min}$ at $94^{\circ} \mathrm{C}$ followed by 25 cycles of $30 \mathrm{~s}$ at $94^{\circ} \mathrm{C}, 1 \mathrm{~min}$ at $58^{\circ} \mathrm{C}$, and $1 \mathrm{~min}$ at $72{ }^{\circ} \mathrm{C}$, with a final extension of $10 \mathrm{~min}$ at $72{ }^{\circ} \mathrm{C}$.

For silver resistance, silA, silB, and silE genes were screened [97]. E. coli J53 and E. coli J53 pMG101 were negative and positive controls, respectively. PCR reactions were carried out under the following conditions: one cycle of denaturation for $3 \mathrm{~min}$ at $95^{\circ} \mathrm{C}$ followed by 30 cycles of $30 \mathrm{~s}$ at $95^{\circ} \mathrm{C}, 30 \mathrm{~s}$ at $54^{\circ} \mathrm{C}$, and $1 \mathrm{~min}$ at $72{ }^{\circ} \mathrm{C}$, with a final extension of $5 \mathrm{~min}$ at $72^{\circ} \mathrm{C}$. The markers with $100 \mathrm{bp}$ (for silB and silE) and $1000 \mathrm{bp}$ (silA) DNA size were used in each gel (Table 4).

For mercury resistance of mer $A$ and merC genes [99], as well as intl1 [100] detection, $25 \mu \mathrm{L}$ reaction mixture contained $2.5 \mu \mathrm{L} 10 \times$ Buffer, $2 \mu \mathrm{L}(2.5 \mathrm{mM})$ of each of the dNTPs, $0.5 \mu \mathrm{L}(10 \mu \mathrm{M})$ of each primer, $0.125 \mu \mathrm{L}(5 \mathrm{U} / \mu \mathrm{L})$ DreamTaq (ThermoFisher Scientific, UK), $1 \mu \mathrm{L}$ DNA template, and $18.375 \mu \mathrm{L}$ of molecular biological grade water. The strains, E. coli J53 and E. coli J53 pMG101, were used as negative and positive controls, respectively. PCR reactions were carried out under the following conditions: one cycle of denaturation for $5 \mathrm{~min}$ at $95^{\circ} \mathrm{C}$ followed by 30 cycles of $30 \mathrm{~s}$ at $95^{\circ} \mathrm{C}, 30 \mathrm{~s}$ at $67{ }^{\circ} \mathrm{C}$, and $1 \mathrm{~min}$ at $72{ }^{\circ} \mathrm{C}$, with a final extension of $5 \mathrm{~min}$ at $72{ }^{\circ} \mathrm{C}$.

For copper resistance of $p c o E$ gene detection, total DNA $(1 \mu \mathrm{L})$ was used in a $25 \mu \mathrm{L}$ reaction mixture that contained $2.5 \mu \mathrm{L} 10 \times$ Buffer, $2 \mu \mathrm{L}(2.5 \mathrm{mM})$ of each of the dNTPs, $2 \mu \mathrm{L}$ (10) $\mu \mathrm{M}$ of each primer, $0.125 \mu \mathrm{L}(5 \mathrm{U} / \mu \mathrm{L}$ ) DreamTaq (ThermoFisher Scientific, UK), and $15.375 \mu \mathrm{L}$ of molecular biological grade water. The strains, E. coli ED8739 and E. coli ED8739 pRJ1004, were as negative and 
positive controls, respectively. PCR reactions were carried out under the following conditions: one cycle of denaturation for $5 \mathrm{~min}$ at $95^{\circ} \mathrm{C}$ followed by 30 cycles of $30 \mathrm{~s}$ at $95^{\circ} \mathrm{C}, 30 \mathrm{~s}$ at $48^{\circ} \mathrm{C}$, and $1 \mathrm{~min}$ at $72{ }^{\circ} \mathrm{C}$, with a final extension of $5 \mathrm{~min}$ at $72{ }^{\circ} \mathrm{C}$.

For visualisation of the PCR products, the PCR product $(7 \mu \mathrm{L})$ with loading buffer $(3 \mu \mathrm{L})$ was loaded onto a $1.5 \% \mathrm{w} / \mathrm{v}$ agarose gel, containing ethidium bromide $(0.4 \mu \mathrm{g} / \mathrm{mL})$ in $1 \times$ TAE running buffer ( $40 \mathrm{mM}$ Tris-acetate, $1 \mathrm{mM}$ EDTA) and electrophoresed at $100 \mathrm{~V}$ for $1 \mathrm{~h}$.

Table 4. Polymerase chain reaction (PCR) primers used for detection of $\beta$-lactamase genes and metal resistance genes.

\begin{tabular}{|c|c|c|c|}
\hline Oligonucleotide Name & Sequence $^{\mathrm{a}}$ & oduct Size (Bp) & Reference \\
\hline ast $A-\mathrm{F}$ & CCATCAACACAGTATATCCGA & 111 & [98] \\
\hline ast $A-\mathrm{R}$ & GGTCGCGAGTGACGGCTTTGT & & \\
\hline CTX-M-F & ATGTGCAGYACCAGTAARGTKATGGC & 529 & [96] \\
\hline CTX-M-R & TGGGTRAARTARGTSACCAGAAYSAGCGG & & \\
\hline TEM-F & GCGGAACCCCTATTTG & 964 & \\
\hline TEM-R & ACCAATGCTTAATCAGTGAG & & \\
\hline SHV-F & TTATCTCCСTGTTAGCCACC & 796 & \\
\hline SHV-R & GATTTGCTGATTTCGCTCGG & & \\
\hline OXA-1-F & ATGAAAAACACAATACATATCAACTTCGC & 820 & \\
\hline OXA-1-R & GTGTGTTTAGAATGGTGATCGCATT & & \\
\hline$m c r-1-\mathrm{F}$ & CGGTCAGTCCGTTTGTTC & 309 & [32] \\
\hline$m c r-1-\mathrm{R}$ & CTTGGTCGGTCTGTAGGG & & \\
\hline merA-F & ACCATCGGCACCTGCGT & 1237 & [99] \\
\hline merA-R & ACCATCGTCAGGTAGGGGAACAA & & \\
\hline merC-F & CATCGGGCTGGGCTGGGCTTCTTGAG & 364 & \\
\hline merC-R & CATCGTTCCTTATTCGTGTGG & & \\
\hline intl1-F & CCTCCCGCACGATGATC & 280 & [100] \\
\hline intl1-R & TCCACGCATCGTCAGGC & & \\
\hline silA-F & ATGATTGAATGGATTATCCG & 3147 & [97] \\
\hline silA-R & TTATGACACGCTTTTTTTAT & & \\
\hline silB-F & ATGGCTTCTTTAAAGATAAA & 1293 & \\
\hline silB-R & TCAGTGCCCTGAATGCATAT & & \\
\hline silE-F & ATGAAAAATATCGTATTAGC & 432 & \\
\hline silE-R & TCAGCCTGCACTGAGCATGC & & \\
\hline$p c o E-F$ & ATGAATATATTAATCACGAC & 450 & \\
\hline pcoE-R & TTACCTGGTCGAATACAGCC & & \\
\hline
\end{tabular}

\section{Conclusions}

In this study, we have examined the phenotypic and genotypic resistances to 18 antibiotics and 3 metals (mercury, silver, and copper) of E. coli isolated between 2007 and 2010 from pig slaughterhouses in the United Kingdom. The results showed resistances to oxytetracycline, streptomycin, sulphonamide, ampicillin, chloramphenicol, trimethoprim-sulfamethoxazole, ceftiofur, amoxicillin-clavulanic acid, aztreonam, and nitrofurantoin. The top three resistances were oxytetracycline $(64 \%)$, streptomycin $(28 \%)$, and sulphonamide $(16 \%)$. Two strains were resistant to six kinds of antibiotics. Three carried the bla $a_{\mathrm{TEM}}$ gene. Fifteen strains $(18.75 \%)$ were resistant to $25 \mu \mathrm{g} / \mathrm{mL}$ mercury and five $(6.25 \%)$ of these to $50 \mu \mathrm{g} / \mathrm{mL} ;$ merA and $m e r C$ genes were detected in 14 strains. Thirty-five strains $(43.75 \%)$ showed resistance to silver, with 19 possessing silA, silB, and silE genes. Fifty-five strains $(68.75 \%)$ were resistant to $8 \mathrm{mM}$ copper or above. Seven contained the $p c o E$ gene. Some strains were multi-resistant to antibiotics, silver, and copper. These results indicate the potential for high-risk, multi-drug (metal and antibiotics) resistant strains to enter the food chain and co-selection between antibiotic and metal might exist in E. coli isolates, and will aid understanding about the effects of strategies to reduce resistance and mechanisms of antimicrobial resistance (AMR).

Supplementary Materials: The following are available online at http://www.mdpi.com/2079-6382/9/11/0746/s1, Table S1: All 81 strains information. 
Author Contributions: Conceptualization, C.E.R.D. and J.L.H.; methodology, H.Y., S.-H.W., C.E.R.D., and J.L.H.; resources, S.-H.W. and C.E.R.D.; data curation, H.Y. and C.E.R.D.; writing-original draft preparation, H.Y.; writing-review and editing, H.Y., C.E.R.D., and J.L.H. All authors have read and agreed to the published version of the manuscript.

Funding: This research was funded by China Scholarship Council and supported by the China Fundamental Research Fund for Central Universities (2572018BD03), China Scholarship Council and Ministry of Education, Republic of China (Taiwan).

Acknowledgments: The authors thanks Charlotte Gray-Hammerton, Constantina Apostolou, Steve Hootan, Joe Ingram, and Alex Pritchard for their technical help. The authors also thanks Ben Niu for his suggestions on data analysis.

Conflicts of Interest: The authors declare no conflict of interest. The funders had no role in the design of the study; in the collection, analyses, or interpretation of data; in the writing of the manuscript; or in the decision to publish the results.

\section{References}

1. Hudson, J.A.; Frewer, L.J.; Jones, G.; Brereton, P.A.; Whittingham, M.J.; Stewart, G. The agri-food chain and antimicrobial resistance: A review. Trends Food Sci. Technol. 2017, 69, 131-147. [CrossRef]

2. Zhou, B.; Wang, C.; Zhao, Q.; Wang, Y.; Huo, M.; Wang, J.; Wang, S. Prevalence and dissemination of antibiotic resistance genes and coselection of heavy metals in Chinese dairy farms. J. Hazard. Mater. 2016, 320, $10-17$. [CrossRef] [PubMed]

3. Teuber, M. Veterinary use and antibiotic resistance. Curr. Opin. Microbiol. 2001, 4, 493-499. [CrossRef]

4. Wright, G.D. Antibiotic resistance in the environment: A link to the clinic? Curr. Opin. Microbiol. 2010, 13, 589-594. [CrossRef]

5. Qiao, M.; Ying, G.G.; Singer, A.C.; Zhu, Y.G. Review of antibiotic resistance in China and its environment. Environ. Int. 2018, 110, 160-172. [CrossRef]

6. Hobman, J.L.; Crossman, L.C. Bacterial antimicrobial metal ion resistance. J. Med. Microbiol. 2015, 64, 471-497. [CrossRef]

7. He, X.; Xu, Y.; Chen, J.; Ling, J.; Li, Y.; Huang, L.; Zhou, X.; Zheng, L.; Xie, G. Evolution of corresponding resistance genes in the water of fish tanks with multiple stresses of antibiotics and heavy metals. Water Res. 2017, 124, 39-48. [CrossRef]

8. Nicholson, F.A.; Smith, S.R.; Alloway, B.J.; Carlton-Smith, C.; Chambers, B.J. An inventory of heavy metals inputs to agricultural soils in England and Wales. Sci. Total. Environ. 2003, 311, 205-219. [CrossRef]

9. Li, Y.X.; Li, W.; Wu, J.; Xu, L.C.; Su, Q.H.; Xiong, X. Contribution of additives Cu to its accumulation in pig feces: Study in Beijing and Fuxin of China. J. Environ. Sci. 2007, 19, 610-615. [CrossRef]

10. Li, L.; Xu, Z.; Wu, J.; Tian, G. Bioaccumulation of heavy metals in the earthworm Eisenia fetida in relation to bioavailable metal concentrations in pig manure. Bioresour. Technol. 2010, 101, 3430-3436. [CrossRef]

11. Holzel, C.S.; Muller, C.; Harms, K.S.; Mikolajewski, S.; Schafer, S.; Schwaiger, K.; Bauer, J. Heavy metals in liquid pig manure in light of bacterial antimicrobial resistance. Environ. Res. 2012, 113, 21-27. [CrossRef] [PubMed]

12. Parkhill, J.; Dougan, G.; James, K.D.; Thomson, N.R.; Pickard, D.; Wain, J.; Churcher, C.; Mungall, K.L.; Bentley, S.D.; Holden, M.T.G. Complete genome sequence of a multiple drug resistant Salmonella enterica serovar Typhi CT18. Nature 2001, 413, 848-852. [CrossRef]

13. Akinbowale, O.L.; Peng, H.; Grant, P.; Barton, M.D. Antibiotic and heavy metal resistance in motile aeromonads and pseudomonads from rainbow trout (Oncorhynchus mykiss) farms in Australia. Int. J. Antimicrob. Agents 2007, 30, 177-182. [CrossRef] [PubMed]

14. Najiah, M.; Lee, S.W.; Wendy, W.; Tee, L.W.; Nadirah, M.; Faizah, S.H. Antibiotic Resistance and Heavy Metals Tolerance in Gram-Negative Bacteria from Diseased American Bullfrog (Rana catesbeiana) Cultured in Malaysia. Agric. Sci. China 2009, 8, 1270-1275. [CrossRef]

15. Alonso, A.; Sanchez, P.; Martinez, J.L. Environmental selection of antibiotic resistance genes. Environ. Microbiol. 2001, 3, 1-9. [CrossRef]

16. Baker-Austin, C.; Wright, M.S.; Stepanauskas, R.; McArthur, J.V. Co-selection of antibiotic and metal resistance. Trends Microbiol. 2006, 14, 176-182. [CrossRef] 
17. Zhang, M.; Chen, L.; Ye, C.; Yu, X. Co-selection of antibiotic resistance via copper shock loading on bacteria from a drinking water bio-filter. Environ. Pollut. 2018, 233, 132-141. [CrossRef]

18. McAuliffe, G.A.; Takahashi, T.; Mogensen, L.; Hermansen, J.E.; Sage, C.L.; Chapman, D.V.; Lee, M.R.F. Environmental trade-offs of pig production systems under varied operational efficiencies. J. Clean Prod. 2017, 165, 1163-1173. [CrossRef]

19. Sheridan, J.J. Sources of contamination during slaughter and measures for control. J. Food Saf. 1998, 18, 321-339. [CrossRef]

20. Wheatley, P.; Giotis, E.S.; McKevitt, A.I. Effects of slaughtering operations on carcass contamination in an Irish pork production plant. Ir. Vet. J. 2014, 67, 1. [CrossRef]

21. Martins, B.T.F.; Botelho, C.V.; Silva, D.A.L.; Lanna, F.; Grossi, J.L.; Campos-Galvao, M.E.M.; Yamatogi, R.S.; Falcao, J.P.; Bersot, L.D.S.; Nero, L.A. Yersinia enterocolitica in a Brazilian pork production chain: Tracking of contamination routes, virulence and antimicrobial resistance. Int. J. Food Microbiol. 2018, 276, 5-9. [CrossRef] [PubMed]

22. Warriner, K.; Aldsworth, T.G.; Kaur, S.; Dodd, C.E. Cross-contamination of carcasses and equipment during pork processing. J. Appl. Microbiol. 2002, 93, 169-177. [CrossRef]

23. Bouvet, J.; Bavai, C.; Rossel, R.; Le Roux, A.; Montet, M.P.; Ray-Gueniot, S.; Mazuy, C.; Arquillière, C.; Vernozy-Rozand, C. Prevalence of verotoxin-producing Escherichia coli and E. coli O157:H7 in pig carcasses from three French slaughterhouses. Int. J. Food Microbiol. 2001, 71, 249-255. [CrossRef]

24. Morales-Partera, A.M.; Cardoso-Toset, F.; Luque, I.; Astorga, R.J.; Maldonado, A.; Herrera-León, S.; Hernández, M.; Gómez-Laguna, J.; Tarradas, C. Prevalence and diversity of Salmonella spp., Campylobacter spp., and Listeria monocytogenes in two free-range pig slaughterhouses. Food Control 2018, 92, 208-215. [CrossRef]

25. Eblen, D.R.; Annous, B.A.; Sapers, G.M. Studies to select appropriate nonpathogenic surrogate Escherichia coli strains for potential use in place of Escherichia coli O157:H7 and salmonella in pilot plant studiest. J. Food Prot. 2005, 68, 282-291. [CrossRef]

26. Hartl, D.L.; Dykhuizen, D. The Population Genetics of Escherichia Coli. Annu. Rev. Genet. 1984, 18, 31-68. [CrossRef] [PubMed]

27. Nataro, J.P.; Kaper, J.B. Diarrheagenic Escherichia coli. Clin. Microbiol. Rev. 1998, 11, 403. [CrossRef]

28. Botteldoorn, N.; Heyndrickx, M.; Rijpens, N.; Herman, L. Detection and characterization of verotoxigenic Escherichia coli by a VTEC/EHEC multiplex PCR in porcine faeces and pig carcass swabs. Res. Microbiol. 2003, 154, 97-104. [CrossRef]

29. Ojo, O.E.; Ajuwape, A.T.; Otesile, E.B.; Owoade, A.A.; Oyekunle, M.A.; Adetosoye, A.I. Potentially zoonotic shiga toxin-producing Escherichia coli serogroups in the faeces and meat of food-producing animals in Ibadan, Nigeria. Int. J. Food Microbiol. 2010, 142, 214-221. [CrossRef]

30. Martinez-Vazquez, A.V.; Rivera-Sanchez, G.; Lira Mendez, K.; Reyes-Lopez, M.A.; Bocanegra-Garcia, V. Prevalence, antimicrobial resistance and virulence genes in Escherichia coli isolated from retail meats in Tamaulipas, Mexico. J. Glob. Antimicrob. Resist. 2018, 14, 266-272. [CrossRef] [PubMed]

31. Burger, R. EHEC O104:H4 in Germany 2011: Large Outbreak of Bloody Diarrhea and Haemolytic Uraemic Syndrome by Shiga Toxin-Producing E. coli via Contaminated Food; Robert Koch-Institut: Berlin, Germany, 2012. [CrossRef]

32. Liu, Y.Y.; Wang, Y.; Walsh, T.R.; Yi, L.X.; Zhang, R.; Spencer, J.; Doi, Y.; Tian, G.; Dong, B.; Huang, X.; et al. Emergence of plasmid-mediated colistin resistance mechanism MCR-1 in animals and human beings in China: A microbiological and molecular biological study. Lancet Infect. Dis. 2016, 16, 161-168. [CrossRef]

33. Van Noten, N.; Gorissen, L.; De Smet, S. Assistance Update SLR: Copper and antibiotic resistance in pigs. EFSA Supporting Publ. 2016, 13, 1005E. [CrossRef]

34. Halik, K.A. Preservation of some extremely thermophilic chemolithoautotrophic bacteria by deep-freezing and liquid-drying methods. J. Microbiol. Methods 1999, 35, 177-182. [CrossRef]

35. Zhang, H.; Cai, L.; Zhang, F.; Ge, C.; Yang, F. Vacuum lyophilization preservation and rejuvenation performance of anammox bacteria. J. Biosci. Bioeng. 2020, 129, 519-527. [CrossRef]

36. Lakshman, D.K.; Singh, V.; Camacho, M.E. Long-term cryopreservation of non-spore-forming fungi in Microbank ${ }^{\mathrm{TM}}$ beads for plant pathological investigations. J. Microbiol. Methods 2018, 148, 120-126. [CrossRef]

37. Wei, S.H. Escherichia coli Contamination of Pork Carcasses in UK Slaughterhouses; The University of Nottingham: Nottingham, UK, 2012. 
38. Ibrahim, D.R.; Dodd, C.E.; Stekel, D.J.; Ramsden, S.J.; Hobman, J.L. Multidrug resistant, extended spectrum beta-lactamase (ESBL)-producing Escherichia coli isolated from a dairy farm. FEMS Microbiol. Ecol. 2016, 92, 1-12. [CrossRef]

39. CLSI. Methods for Dilution Antimicrobial Susceptibility Tests for Bacteria That Grow Aerobically, 11th ed.; CLSI standard M07; Clinical and Laboratory Standards Institute: Wayne, PA, USA, 2018.

40. CLSI. Performance Standards for Antimicrobial Disk and Dilution Susceptibility Tests for Bacteria Isolated from Animals, 5th ed.; CLSI standard VET01; Clinical and Laboratory Standards Institute: Wayne, PA, USA, 2018.

41. CLSI. Performance Standards for Antimicrobial Disk Susceptibility Tests, 13th ed.; CLSI standard M02; Clinical and Laboratory Standards Institute: Wayne, PA, USA, 2018.

42. Colom, K.; Pérez, J.; Alonso, R.; Fernández-Aranguiz, A.; Lariño, E.; Cisterna, R. Simple and reliable multiplex PCR assay for detection of blaTEM, blaSHV and blaOXA-1 genes in Enterobacteriaceae. FEMS Microbiol. Lett. 2003, 223, 147-151. [CrossRef]

43. World Health Organization. Global Acton Plan on Antimicrobial Resistance; WHO: Geneva, Switzerland, 2015.

44. Hwang, A.Y.; Gums, J.G. The emergence and evolution of antimicrobial resistance: Impact on a global scale. Bioorganic Med. Chem. 2016, 24, 6440-6445. [CrossRef]

45. Laxminarayan, R.; Duse, A.; Wattal, C.; Zaidi, A.K.; Wertheim, H.F.; Sumpradit, N.; Vlieghe, E.; Hara, G.L.; Gould, I.M.; Goossens, H.; et al. Antibiotic resistance-the need for global solutions. Lancet Infect. Dis. 2013, 13, 1057-1098. [CrossRef]

46. Rankin, S.; Roberts, S.; O'Shea, K.; Maloney, D.; Lorenzo, M.; Benson, C.E. Panton valentine leukocidin (PVL) toxin positive MRSA strains isolated from companion animals. Vet. Microbiol. 2005, 108, 145-148. [CrossRef]

47. García-González, P.; García-Lamas, N.; Fuentes Edfuf, C.; Santos, Y. Development of a PCR method for the specific identification of the marine fish pathogen Tenacibaculum soleae. Aquaculture 2011, 319, 1-4. [CrossRef]

48. Kaper, J.B.; Nataro, J.P.; Mobley, H.L. Pathogenic Escherichia coli. Nat. Rev. Microbiol. 2004, 2, $123-140$. [CrossRef] [PubMed]

49. Sheikh, A.A.; Checkley, S.; Avery, B.; Chalmers, G.; Bohaychuk, V.; Boerlin, P.; Reid-Smith, R.; Aslam, M. Antimicrobial resistance and resistance genes in Escherichia coli isolated from retail meat purchased in Alberta, Canada. Foodborne Pathog Dis. 2012, 9, 625-631. [CrossRef]

50. Llorente, P.; Barnech, L.; Irino, K.; Rumi, M.V.; Bentancor, A. Characterization of Shiga toxin-producing Escherichia coli isolated from ground beef collected in different socioeconomic strata markets in Buenos Aires, Argentina. Biomed. Res. Int. 2014, 2014, 795104. [CrossRef]

51. Tadesse, D.A.; Zhao, S.; Tong, E.; Ayers, S.; Singh, A.; Bartholomew, M.J.; McDermott, P.F. Antimicrobial drug resistance in Escherichia coli from humans and food animals, United States, 1950-2002. Emerg. Infect Dis. 2012, 18, 741-749. [CrossRef] [PubMed]

52. Gao, P.; Munir, M.; Xagoraraki, I. Correlation of tetracycline and sulfonamide antibiotics with corresponding resistance genes and resistant bacteria in a conventional municipal wastewater treatment plant. Sci. Total Environ. 2012, 421, 173-183. [CrossRef]

53. Harja, M.; Ciobanu, G. Studies on adsorption of oxytetracycline from aqueous solutions onto hydroxyapatite. Sci. Total Environ. 2018, 628, 36-43. [CrossRef]

54. Zhang, S.; Qu, Q.; Zhang, J.; Lai, Z.; Zhu, X. Prevalence, genetic diversity, and antibiotic resistance of enterotoxigenic Escherichia coli in retail ready-to-eat foods in China. Food Control 2016, 68, 236-243. [CrossRef]

55. Skočková, A.; Koláčková, I.; Bogdanovičová, K.; Karpíšková, R. Characteristic and antimicrobial resistance in Escherichia coli from retail meats purchased in the Czech Republic. Food Control 2015, 47, 401-406. [CrossRef]

56. EMEA. Antibiotic Resistance in the European Union Associated with the Therapeutic Use of Veterinary Medicines. European Agency for the Evaluation of Medicinal Products; Report EMEA/CVMP/342/99-Final; Veterinary Medicines Evaluation Unit: London, UK, 1999.

57. Abo-Amer, A.E.; Shobrak, M.Y.; Altalhi, A.D. Isolation and antimicrobial resistance among Escherichia coli isolated from farm chickens in Taif province, Saudi Arabia. J. Glob. Antimicrob. Resist. 2018. [CrossRef]

58. Aragaw, K.; Molla, B.; Muckle, A.; Cole, L.; Wilkie, E.; Poppe, C.; Kleer, J.; Hildebrandt, G. The characterization of Salmonella serovars isolated from apparently healthy slaughtered pigs at Addis Ababa abattoir, Ethiopia. Prev. Vet. Med. 2007, 82, 252-261. [CrossRef] [PubMed] 
59. Bonardi, S.; Alpigiani, I.; Bruini, I.; Barilli, E.; Brindani, F.; Morganti, M.; Cavallini, P.; Bolzoni, L.; Pongolini, S. Detection of Salmonella enterica in pigs at slaughter and comparison with human isolates in Italy. Int. J. Food Microbiol. 2016, 218, 44-50. [CrossRef]

60. Wu, S.; Dalsgaard, A.; Vieira, A.R.; Emborg, H.-D.; Jensen, L.B. Prevalence of tetracycline resistance and genotypic analysis of populations of Escherichia coli from animals, carcasses and cuts processed at a pig slaughterhouse. Int. J. Food Microbiol. 2009, 135, 254-259. [CrossRef] [PubMed]

61. Bonardi, S.; Bruini, I.; D'Incau, M.; Van Damme, I.; Carniel, E.; Bremont, S.; Cavallini, P.; Tagliabue, S.; Brindani, F. Detection, seroprevalence and antimicrobial resistance of Yersinia enterocolitica and Yersinia pseudotuberculosis in pig tonsils in Northern Italy. Int. J. Food Microbiol. 2016, 235, 125-132. [CrossRef] [PubMed]

62. de Jong, A.; Simjee, S.; Garch, F.E.; Moyaert, H.; Rose, M.; Youala, M.; Dry, M.; Group, E.S. Antimicrobial susceptibility of enterococci recovered from healthy cattle, pigs and chickens in nine EU countries (EASSA Study) to critically important antibiotics. Vet. Microbiol. 2018, 216, 168-175. [CrossRef] [PubMed]

63. Ozgumus, O.B.; Celik-Sevim, E.; Alpay-Karaoglu, S.; Sandalli, C.; Sevim, A. Molecular characterization of antibiotic resistant Escherichia coli strains isolated from tap and spring waters in a coastal region in turkey. J. Microbiol. 2007, 45, 379-387.

64. DANMAP. DANMAP 2005-Use of Antimicrobial Agents and Occurrence of Antimicrobial Resistance in Bacteria from Food Animals, Foods, and Humans in Denmark; Danish Institute for Food and Veterinary Research: Copenhagen, Denmark, 2006.

65. Schwaiger, K.; Huther, S.; Holzel, C.; Kampf, P.; Bauer, J. Prevalence of antibiotic-resistant Enterobacteriaceae isolated from chicken and pork meat purchased at the slaughterhouse and at retail in Bavaria, Germany. Int. J.'Food Microbiol. 2012, 154, 206-211. [CrossRef]

66. Sudarwanto, M.B.; Lukman, D.W.; Purnawarman, T.; Latif, H.; Pisestyani, H.; Sukmawinata, E. Multidrug resistance extended spectrum $\beta$-lactamase and AmpC producing Escherichia coli isolated from the environment of Bogor Slaughterhouse, Indonesia. Asian Pac. J. Trop. Biomed. 2017, 7, 708-711. [CrossRef]

67. Ishihara, K.; Hosokawa, Y.; Makita, K.; Noda, J.; Ueno, H.; Muramatsu, Y.; Ueno, H.; Mukai, T.; Yamamoto, H.; Ito, M.; et al. Factors associated with antimicrobial-resistant Escherichia coli in zoo animals. Res. Vet. Sci. 2012, 93, 574-580. [CrossRef]

68. Pitout, J.D.D.; Laupland, K.B. Extended-spectrum $\beta$-lactamase-producting Enterobacteriaceae: An emerging public-health concern. Lancet Infect. Dis. 2008, 8, 159-166. [CrossRef]

69. Bradford, P.A. Extended-spectrum $\beta$-lactamases in the 21st century: Characterization, epidemiology, and detection of this important resistance threat. Clin. Microbiol. Rev. 2001, 14, 933-951. [CrossRef] [PubMed]

70. Reinthaler, F.F.; Feierl, G.; Galler, H.; Haas, D.; Leitner, E.; Mascher, F.; Melkes, A.; Posch, J.; Winter, I.; Zarfel, G.; et al. ESBL-producing E. coli in Austrian sewage sludge. Water Res. 2010, 44, 1981-1985. [CrossRef] [PubMed]

71. Costa, D.; Vinué, L.; Poeta, P.; Coelho, A.C.; Matos, M.; Sáenz, Y.; Somalo, S.; Zarazaga, M.; Rodrigues, J.; Torres, C. Prevalence of extended-spectrum beta-lactamase-producing Escherichia coli isolates in faecal samples of broilers. Vet. Microbiol. 2009, 138, 339-344. [CrossRef]

72. Ojer-Usoz, E.; Gonzalez, D.; Vitas, A.I.; Leiva, J.; Garcia-Jalon, I.; Febles-Casquero, A.; Escolano Mde, L. Prevalence of extended-spectrum beta-lactamase-producing Enterobacteriaceae in meat products sold in Navarra, Spain. Meat Sci. 2013, 93, 316-321. [CrossRef]

73. Peter, S.; Polsfuss, S.; Poledica, M.; Hombach, M.; Giger, J.; Böttger, E.; Zbinden, R.; Bloemberg, G. Detection of AmpC Beta-Lactamase in Escherichia coli: Comparison of Three Phenotypic Confirmation Assays and Genetic Analysis. J. Clin. Microbiol. 2011, 49, 2924-2932. [CrossRef] [PubMed]

74. Philippon, A.; Arlet, G.; Lagrange, P.H. Origin and impact of plasmid-mediated extended-spectrum beta-lactamases. Eur. J. Clin. Microbiol. Infect. Dis. 1994, 13, S17-S29. [CrossRef] [PubMed]

75. Fernandez-Alarcon, C.; Singer, R.S.; Johnson, T.J. Comparative genomics of multidrug resistance-encoding IncA/C plasmids from commensal and pathogenic Escherichia coli from multiple animal sources. PLoS ONE 2011, 6, e23415. [CrossRef]

76. Yu, Z.; Gunn, L.; Wall, P.; Fanning, S. Antimicrobial resistance and its association with tolerance to heavy metals in agriculture production. Food Microbiol. 2017, 64, 23-32. [CrossRef]

77. Barkay, T.; Miller, S.M.; Summers, A.O. Bacterial mercury resistance from atoms to ecosystems. FEMS Microbiol. Rev. 2003, 27, 355-384. [CrossRef] 
78. Pal, C.; Asiani, K.; Arya, S.; Rensing, C.; Stekel, D.J.; Larsson, D.G.J.; Hobman, J.L. Chapter Seven-Metal Resistance and Its Association With Antibiotic Resistance. In Advances in Microbial Physiology; Poole, R.K., Ed.; Academic Press: Cambridge, MA, USA, 2017; Volume 70, pp. 261-313.

79. Olson, B.H.; Lester, J.N.; Cayless, S.M.; Ford, S. Distribution of mercury resistance determinants in bacterial communities of river sediments. Water Res. 1989, 23, 1209-1217. [CrossRef]

80. Mazel, D.; Dychinco, B.; Webb, V.A.; Davies, J. Antibiotic resistance in the ECOR collection: Integrons and identification of a novel aad gene. Antimicrob. Agents Chemother. 2000, 44, 1568-1574. [CrossRef] [PubMed]

81. Gupta, A.; Maynes, M.; Silver, S. Effects of halides on plasmid-mediated silver resistance in Escherichia coli. Appl. Environ. Microbiol. 1998, 64, 5042-5045. [CrossRef] [PubMed]

82. Gupta, A.; Matsui, K.; Lo, J.-F.; Silver, S. Molecular basis for resistance to silver cations in Salmonella. Nat. Med. 1999, 5, 183. [CrossRef] [PubMed]

83. Silver, S. Bacterial silver resistance: Molecular biology and uses and misuses of silver compounds. FEMS Microbiol. Rev. 2003, 27, 341-353. [CrossRef]

84. Solioz, M.; Abicht, H.K.; Mermod, M.; Mancini, S. Response of Gram-positive bacteria to copper stress. J. Biol. Inorg. Chem. 2010, 15, 3-14. [CrossRef]

85. Debski, B. Supplementation of pigs diet with zinc and copper as alternative to conventional antimicrobials. Pol. J. Vet. Sci. 2016, 19, 917-924. [CrossRef]

86. Agga, G.E.; Scott, H.M.; Amachawadi, R.G.; Nagaraja, T.G.; Vinasco, J.; Bai, J.; Norby, B.; Renter, D.G.; Drita, S.S.; Nelssen, J.L.; et al. Effects of chlortetracycline and copper supplementation on antimicrobial resistance of fecal Escherichia coli from weaned pigs. Prev. Vet. Med. 2014, 114, 231-246. [CrossRef]

87. Marazzato, M.; Aleandri, M.; Massaro, M.R.; Vitanza, L.; Conte, A.L.; Conte, M.P.; Nicoletti, M.; Comanducci, A.; Goldoni, P.; Maurizi, L.; et al. Escherichia coli strains of chicken and human origin: Characterization of antibiotic and heavy-metal resistance profiles, phylogenetic grouping, and presence of virulence genetic markers. Res. Vet. Sci. 2020, 132, 150-155. [CrossRef]

88. Najar, I.N.; Sherpa, M.T.; Das, S.; Das, S.; Thakur, N. Diversity analysis and metagenomic insights into antibiotic and metal resistance among Himalayan hot spring bacteriobiome insinuating inherent environmental baseline levels of antibiotic and metal tolerance. J. Glob. Antimicrob. Resist. 2020, 21, 342-352. [CrossRef]

89. Veterinary Medicines Directorate. UK-VARSS 2018 Highlights Report. Available online: https://www.gov. uk/government/publications/veterinary-antimicrobial-resistance-and-sales-surveillance-2018 (accessed on 7 September 2020).

90. Kempf, I.; Jouy, E.; Chauvin, C. Colistin use and colistin resistance in bacteria from animals. Int. J. Antimicrob. Agents 2016, 48, 598-606. [CrossRef]

91. Gupta, A.; Phung, L.T.; Taylor, D.E.; Silver, S. Diversity of silver resistance genes in IncH incompatibility group plasmids. Microbiology 2001, 147, 3393-3402. [CrossRef] [PubMed]

92. Mourão, J.; Novais, C.; Machado, J.; Peixe, L.; Antunes, P. Metal tolerance in emerging clinically relevant multidrug-resistant Salmonella enterica serotype 4,[5],12:i:-clones circulating in Europe. Int. J. Antimicrob. Agents 2015, 45, 610-616. [CrossRef]

93. Borck, K.; Beggs, J.D.; Brammar, W.J.; Hopkins, A.S.; Murray, N.E. The construction in vitro of transducing derivatives of phage lambda. Mol. Gen. Genet. MGG 1976, 146, 199-207. [CrossRef]

94. Tetaz, T.J.; Luke, R.K. Plasmid-controlled resistance to copper in Escherichia coli. J. Bacteriol. 1983, 154, 1263-1268. [CrossRef] [PubMed]

95. Yamamoto, T.; Yokota, T. Plasmids of enterotoxigenic Escherichia coli H10407: Evidence for two heat-stable enterotoxin genes and a conjugal transfer system. J. Bacteriol. 1983, 153, 1352. [CrossRef]

96. Dierikx, C.M.; van Duijkeren, E.; Schoormans, A.H.; van Essen-Zandbergen, A.; Veldman, K.; Kant, A.; Huijsdens, X.W.; van der Zwaluw, K.; Wagenaar, J.A.; Mevius, D.J. Occurrence and characteristics of extended-spectrum-beta-lactamase- and AmpC-producing clinical isolates derived from companion animals and horses. J. Antimicrob. Chemother. 2012, 67, 1368-1374. [CrossRef]

97. Asiani, K. Biochemical and Biophysical Studies on SilE from the Sil Silver Resistance Locus; The University of Nottingham: Nottingham, UK, 2016.

98. Jenkins, C.; Tembo, M.; Chart, H.; Cheasty, T.; Willshaw, G.A.; Phillips, A.D.; Tompkins, D.; Smith, H. Detection of enteroaggregative Escherichia coli in faecal samples from patients in the community with diarrhoea. J. Med. Microbiol. 2006, 55, 1493-1497. [CrossRef] [PubMed] 
99. Liebert, C.A.; Wireman, J.; Smith, T.; Summers, A.O. Phylogeny of mercury resistance (mer) operons of gram-negative bacteria isolated from the fecal flora of primates. Appl. Environ. Microbiol. 1997, 63, 1066-1076. [CrossRef]

100. Goldstein, C.; Lee, M.D.; Sanchez, S.; Hudson, C.; Phillips, B.; Register, B.; Grady, M.; Liebert, C.; Summers, A.O.; White, D.G.; et al. Incidence of class 1 and 2 integrases in clinical and commensal bacteria from livestock, companion animals, and exotics. Antimicrob. Agents Chemother. 2001, 45, 723-726. [CrossRef]

Publisher's Note: MDPI stays neutral with regard to jurisdictional claims in published maps and institutional affiliations.

(C) 2020 by the authors. Licensee MDPI, Basel, Switzerland. This article is an open access article distributed under the terms and conditions of the Creative Commons Attribution (CC BY) license (http://creativecommons.org/licenses/by/4.0/). 